\title{
ANTIBACTERIAL ACTIVITY FOR MULTI DRUG RESISTANCE (MDR) BACTERIA BYSEA CUCUMBER Stichopus vastus EXTRACT FROM KARIMUNJAWA ISLANDS - INDONESIA
}

\author{
UJI AKTIFITAS ANTIBAKTERI MULTI DRUG RESISTANCE (MDR) EKSTRAK \\ TERIPANG Stichopus vastus DARI PULAU KARIMUNJAWA - INDONESIA
}

\author{
Delianis Pringgenies*, Ali Ridlo, and Nerva Sembiring \\ Department of Marine Sciences, Faculty of Fisheries and Marine Sciences, \\ Diponegoro University \\ *E-mail: pringgenies@undip.ac.id; pringgenies@yahoo.com
}

\begin{abstract}
The study aims to explore the antibacterial activity of Stichopus vastus against pathogenic MDR bacteria. Analysis of samples of sea cucumbers included extraction, fractionation, and analysis of bacterial sensitivity test Gas Chromatography-Mass Spectrometry (GC-MS), the extraction process is carried out by solid-liquid extraction method. Fractionation was done with Open-Column Chromatography (OCC). Sensitivity test of bacteria was done using an agar diffusion method according to the Kirby-Bauer (Ref). The study revealed that from 5 species MDR bacteria, which are Coagulant negative stapylococi (CNS), E. coli, Enterobacter 5, Klebsiella sp. dan Pseudomonas sp. There are two MDR bacteria had the most sensitive responses by the extract of sea cucumber, which were Enterobacter-5 and Klebsiella sp. The two bacteria were tested against five bioactive fractions obtained from OCC. Fraction criteria- 2 had the highest antibacterial activity against Enterobacter-5 and Klebsiella sp, with serial concentration of $20 \mu \mathrm{g}$ - disc ${ }^{-1}, 40 \mu \mathrm{g}$. disc ${ }^{-1}$ and $80 \mu \mathrm{g}$. disc ${ }^{-1}$. Largest inhibition zone were obtained from $80 \mu \mathrm{g}$. disc ${ }^{-1}$ againts the two bacteria were $(14.73 \pm 0.48) \mathrm{mm}$ and $(11.22 \pm 0.85) \mathrm{mm}$ respectively. GC-MS Analysis revealed that fraction criteria-2 had (or consisted of) cyclohexhane, ethanol, butanoic and pentanoic acids.
\end{abstract}

Keywords: antibacterial activity, multi drug resistance (MDR), sea cucumber, Stichopus vastus

\begin{abstract}
ABSTRAK
Tujuan penelitian adalah untuk mengetahui potensi antibakteri ekstrak teripang dari perairan Karimunjawa terhadap bakteri Multi Drug Resisntant MDR. Analisis sampel teripang meliputi ekstraksi, fraksinasi, dan analisis uji sensitivitas bakteri Kromatografi Gas-Spektrometri Massa (GCMS). Proses ekstraksi dilakukan dengan metode ekstraksi padat-cair. Fraksinasi dilakukan dengan Kromatografi Open-Column (OCC). Uji sensitivitas bakteri dilakukan dengan metode difusi agar sesuai dengan Kirby-Bauer (Ref). Studi tersebut mengungkapkan bahwa dua bakteri MDR memiliki respon paling sensitif dengan ekstrak teripang, yaitu pada bakteri Enterobacter-5 dan Klebsiella sp. Kedua bakteri tersebut diuji terhadap lima fraksi bioaktif yang diperoleh dari OCC. Fraksi 2 memiliki aktivitas antibakteri paling banyak pada Enterobacter-5 dan Klebsiella sp, dengan konsentrasi $20 \mu \mathrm{g} /$ disk, 40 $\mu \mathrm{g} /$ disk dan $80 \mu \mathrm{g} /$ disk. Nilai rata-rata zona hambatan tertinggi terdapat pada konsentrasi $80 \mu \mathrm{g} / d i s k$,

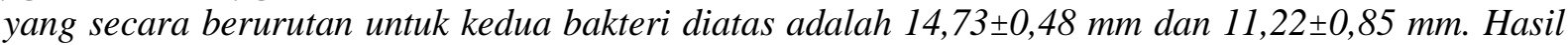
GC-MS menunjukkan bahwa fraksi II mengandung 4 senyawa, yaitu sikloheksena sebagai senyawa dengan kelimpahan terbesar, asam butanoat, asam pentanoat, dan etanol.
\end{abstract}

Kata kunci : aktifitas antibakteri, multi drug resistance (MDR), teripang, Stichopus vastus

\section{INTRODUCTION}

MDR (Multi Drug Resistant) bacteria has defined as bacteria with resistant to a group of antibiotic. This was since the resis- tance as a natural mechanism for bacteria to survive antibiotic. Therefore there must be an important evort in finding and explore new biosubstances for new MDR bacteria. Indonesia marine organism with its geo- 
graphical position had developed a unique environment with high marine biodiversity with high potency of secondary metabolites to be devoped for human health. A group of marine organism with high potency to be developed for secondary metabolites was marine invertebrate. These marine invertebrates has a very limited physical movement compared with other marine vertebrates. So that they developed a good defence system with producing many biosubstances. More specifically these biosusbstances or secondary metabolites were used for self protection especially from microbial infections with assumption that their secondary metabolites have highly prospective as an active biosusbstances against bacterial infections, neurology, anti-inflammatory, anti-virus, and anticancer. One class of marine invertebrate which produce secondary metabolites is sea cucumber (Holothuroidea). The potential of these secondary metabolites from marine organisms and its bacterial symbiont as antibacterial agent was regarded as highly promising for the future (Pringgenies et al., 2001; Pringgenies et al., 2009a; Pringgenies, 2010; Trianto et al., 2004).

One group of marine organism with high potential of bioactive compounds to be developed for natural medicine as alternative way to obtain new secondary metabolites and antibiotic compounds is sea cucumber. Sea cucumber and squid are marine invertebrates with many secondary metabolites compounds which have an important role for the organism self-defense mechanism (Roy, 1982; Pringgenies and Jørgensen, 1994). Potential useful of the secondary metabolites, such as saponin glycosides compounds were exist in sea cucumbers (Hashimoto, 1979). This chemical structure of the active compound was found to be similar to that found in ginseng, ganoderma, and other known medicinal plants. Based on several earlier studies, it was known that these compounds could be developed as anticancer and antibacterial treatments (Sendih and Gunawan, 2006). The fact that sea cucumber as one of the marine lives with its potential agent to generate new compounds that can overcome microorganisms resistance to existing antibiotics. Based on this, the aim of this research was to determine the antibacterial potential of sea cucumber extract from Karimunjawa Islands against multi-drug resistance (MDR) bacteria.

\section{METHODS}

\subsection{Extraction of Sea Cucumbers}

Sea cucumber sampel (size $>15 \mathrm{~cm}$ ) were collected from the islands of Karimunjawa. Sample were cleaned from the dirt and soaked with fresh water for one night to remove salt and parasites that were attached to the body and then dried in a drying cabinet sea cucumber in temperature $<45^{\circ} \mathrm{C}$ for 2 days (Pringgenies, 2013; Farjami et al. 2013). Each of the collected sea cucumber samples was cleaned and cut into $2 \times 2 \mathrm{~cm}$. The samples were then soaked in n-hexane solvent solution at 1:5 ratios. The soaked sample was left under room temperature for $24 \mathrm{~h}$ and then filtered using filtering paper. The extract from the prepared samples was obtained by means of homogenization with hexane (non-polar) and $10 \%$ methanol in chloroform (polar) using a blender. Separation of filtrate from solution was accomplished by using rotary evaporator. The filtrate obtained was crude extract of sea cucumber, that used for further analysis (Farjami et al. 2014).

\subsection{Positive and Negative Control Test to the Tested Bacteria}

Positive control test was done using antibiotic Amoxicillin and streptomycin which were presence in the market with concentration of $20 \mu \mathrm{g} / \mathrm{disc}$. These test aimed to show the resistance zone performed by antibiotic, so that can be comparred with antibacterial performance by exctract of Stichopus vastus. Negative control test was done using three solvent previously used in the exctraction processes, that are n-heksan and methanol to the tested bacteria. This was 
to checked whether there are any effect of the solvent to the perform of resistance zone by the exctract (Burgess et al., 2003).

\subsection{Stichopus vastus Extract Test to the Tested Bacteria (MDR)}

$S$. vastus exctract test to MDR bacteria was done n-heksan, etil acetate, and methanol exctract. Concentration used were $80 \mu \mathrm{g} / \mathrm{disc}$, $40 \mu \mathrm{g} / \mathrm{disc}, 20 \mu \mathrm{g} /$ disc (Nagarajappa and Goswami, 2007). A paper disc was laid down on the plate agar already contain with the MDR bacteria. Then $10 \mu \mathrm{L}$ of $S$. vastus exctract was dropped onto the paper disc with concentration of $8 \mu \mathrm{g} / \mu \mathrm{L}, 4 \mu \mathrm{g} / \mu \mathrm{L}, 2 \mu \mathrm{g} / \mu \mathrm{L}$, $1 \mu \mathrm{g} / \mu \mathrm{L}$ and $0,5 \mu \mathrm{g} / \mu \mathrm{L}$. Observtion of the resistance zone after 24 hour.

\subsection{Thin Layer Chromatography (TLC)}

TLC analysis on the etil acetate $S$. vastus exctract was done using stable phase of silica gel $\mathrm{F}_{254}$ with several combination as a moving fraction. The TLC formed was then sliced with $5 \mathrm{~cm}$ length and $1 \mathrm{~cm}$ width (Gandjar and Rohman, 2007). At every TLC end a $0.5 \mathrm{~cm}$ line from the start to the end TLC. Five percent concentration of the exctract was then gently touched down onto the middle of the start line of the TLC using a capillary syringe. The TLC with addition of exctract was then put into a beaker glass with combination of the three solvent (methanol, etil acetate and n-heksan). Beaker glass was closed tightly until efluent goes to final end, the TLC plate was lifted and dried. Formed spot was observed using UV light (Sthal, 1985) and note the Rf value. Rf value was define as follows (Yazid, 2005):

\subsection{Open Column Chromatography (OCC) \\ OCC analysis was aimed to separate} fraction of biosubstances in the exctract based on its polarity levels (Kristanti dan Aminah, 2008). Etile acetate $S$. vastus 0.4 grams was fractionated using 60-silica gel OCC $(0.2-$
$0.5 \mathrm{~mm}$, Merck) weight 12 gram as solid phase. Etil acetate and chloroform were used with ratio of $3: 1$. Column used was firstly cleaned with solid and flat cotton and solvent at the base of the column to avoid any air buble and a layer of paper disc on top. Silica gel 12 grams was firstly activated in the oven with $120^{\circ} \mathrm{C}$ emperature for 1 hour. Then 10 gram of it was mixed with the solvent for 2 hours, then put into the column solid anf flat to avoid air bubles. On top of the silica gel covered with filter paper and let to form solid plate for 24 hour. Etil acetate $S$. vastus exctract weight of 0.4 grams was diluted in the solvent then add 2 grams of silica gel, mixed with homogenously and keep until solvent had completely evaporated and put into the column which already preparated for 24 hours. Open the column valve with flow of 1 drop/second and countinuously add solvent into the column, where silica gel should kept in soaking with the solvent. Efluante from the column was collected in a vial with volume of $5 \mathrm{~mL}$ for analysis using TLC. Similar spot patern of the column was put together for evaporation.

\subsection{S. vastus Exctract Fraction Activity Test for the MDR Bacteria}

Activity test was done with diffusion methode or disc methode of Kirby-Bauer (Lay, 1994). Each fraction concentration were $80 \mu \mathrm{g} / \mathrm{disc}, 40 \mu \mathrm{g} / \mathrm{disc}$ and $20 \mu \mathrm{g} / \mathrm{disc}$. Antibiotic concentration used was $20 \mu \mathrm{g} / \mathrm{disc}$. Tested bacteria was firstly inoculated in a Nutrient Broth /NB and incubated for 24 hours. Abundance of tested bacteria was 0.5 as in Mc Farland (Naka-mura et al., 1999) and keep for 5 minutes (Lay, 1994). Paper disc was laind down on the agar medium with tested bacteria and then $10 \mu \mathrm{L}$ exctract fraction of etil acetate $S$. vastus slowly dropped onto the paper disc with cconcentration of $8 \mu \mathrm{g} / \mu \mathrm{L}, 4 \mu \mathrm{g} / \mu \mathrm{L}$ and $2 \mu \mathrm{g} / \mu \mathrm{L}$. Observation on the resistance zone was done every 24 hours for three days. Activity test was done for three times. 


\subsection{Gas Chromatography- Mass Spectrometry (GC-MS)}

GC-MS analysis was done for fraction with $0.1 \mathrm{ml}$ volume injection. Column used was Rtx-5Ms with 30 meters length and strat temperature of $80^{\circ} \mathrm{C}$. Capilar diameter was $0.25 \mathrm{~mm}$. Exctract samples injected into the injektor with end temperature of $320^{\circ} \mathrm{C}$ and speed of $10^{\circ} \mathrm{C} /$ minute and will directly evaporated and would be associated with helium gas with speed of $27.3 \mathrm{~cm} / \mathrm{sec}$.

\section{RESULTS AND DISCUSSION}

\section{1. $\quad$ Result}

\subsubsection{Positive and Negative Control Tests}

Positive control test was conducted to determine the effect of commercial antibiotics against inhibition zone formed. Test positive control using antibiotics amoxicillin and streptomycin.

Test positive control with antibiotics amoxicillin showed no zone of inhibition against the test bacteria, but antibiotics streptomycin showed a zone of inhibition against the test bacteria. Negative control test was conducted to determine the effect of the solvent n-hexane, ethyl acetate and methanol in the formation zone of inhibition against the test bacteria.

The volume of solvent being tested against was $10 \mathrm{~mL}$ of test bacteria. If the tests are negative, the diameter of inhibition zone treatment should be reduced by the inhibition zone of solvent

\subsubsection{Antibacterial Assay of Sea Cucumber Extract}

Sea cucumber extract antibacterial activity test was performed using crude extract as much as 0,008 grams and tested against five bacterial strains with multidrug resistance (MDR), which were negative coagulant Stapylococi (CNS), E. coli, Enterobacter 5, Klebsiella sp., Pseudomonas sp. Results of these tests are presented (Table 1).

The test results showed that the activity of the crude extract of sea cucumber with solvent n-hexane showed no antibacterial activity on all kinds of test bacteria. Antibacterial activity can be seen in the rough sea cucumber extract with ethyl acetate solvent for all kinds of test bacteria. Two bacteria with the largest inhibition zone diameter found in 5 Enterobacter and Klebsiella sp., Respectively $13.77 \mathrm{~mm}$ and $12.58 \mathrm{~mm}$. Furthermore, both the bacteria will be used to test the sensitivity of the bacteria to the fraction of sea cucumber extract. While the crude extract of sea cucumber with methanol showed antibacterial activity against CNS bacteria, Enterobacter and Klebsiella sp 5.

\subsubsection{Test Determination of Eluent with Thin Layer Chromatography (TLC)}

Test thin layer chromatography on sea cucumber extract with ethyl acetate solvent, the optimum solvent ratio obtained for the separation of components, namely compounds of ethyl acetate and n-hexane (1:1).

Table 1. Results of antibacterial assay of sea cucumber extract.

Diameter of Inhibition Zone

\begin{tabular}{lccc}
\multirow{2}{*}{ Test Bacteria } & \multicolumn{3}{c}{$(\mathrm{mm})$} \\
\cline { 2 - 4 } & $n$-hexane & Ethyl Acetate & Methanol \\
\hline CNS & 0 & 9.35 & 8.18 \\
E.coli & 0 & 9.50 & 0 \\
Enterobacter-5 & 0 & 13.77 & 8.62 \\
Klebsiela sp. & 0 & 12.58 & 8.75 \\
Pseudomonas $\mathrm{sp}$. & 0 & 0 & 0 \\
\hline
\end{tabular}




\subsubsection{Fractionation by OCC}

The same Rf values were then grouped into a single fraction, and five fractions were finally obtained. Results of TLC, Rf values-and weight of each fraction are shown in Table 2. Grouping results based on $\mathrm{Rf}$ values obtained 5 (five) fraction. Data fractions Rf values of TLC results and weight of each fraction. The results of fractionation with OCC showed that the fraction- $V$ gave the most weight of extract with $0.1429 \mathrm{~g}$ (what basis dry weight?), while the fraction-IV give was the little weight of $0.0325 \mathrm{~g}$.

\subsubsection{Bacterial Sensitivity Test of Sea Cucumber Fractions}

Fractions obtained from column chromatography were tested again open its antibacterial activity. Antibacterial activity test is done only on the test bacteria showed the best sensitivity of the five types of test bacteria used in the activity assay. Antibacterial activity test showed that the ethyl acetate solvent most actively inhibit the growth of bacteria Enterobacter-5 and Klebsiella sp. Test results of bacterial sensi- tivity to sea cucumber extract fractions can be seen in Table 2.

\subsubsection{Sensitivity Test Against Entero- bacter-5}

All fractions of Ethyl acetate extract showed antibacterial activity against Enterobacter 5 (Table 3). Fraction with concentrations of 40 and $80 \mu \mathrm{g}$ per disc had an increasing diameter of inhibition zone at $48 \mathrm{~h}$ of incubation and decreased after $72 \mathrm{~h}$ of incubation. At concentration of $20 \mu \mathrm{g}$ per disc, the inhibition zone decreased to $72 \mathrm{~h}$ of incubation.

Meanwhile II fraction with a concentration of $20 \mu \mathrm{g}$ per disc, the inhibition zone diameter increased $48 \mathrm{~h}$ of incubation and decreased at $72 \mathrm{~h}$ of incubation. While at 40 and $80 \mu \mathrm{g}$ of-II fraction had a decrease inhibition zone as the escalation of the incubation period. Similar pattern were observed in the III, IV, and V fraction at each concentrations. II fraction had the highest activity against Enterobacter-5, while IV fraction had the lowest activity against Enterobacter-5.

Table 2. Results of ethyl acetate extract.

\begin{tabular}{ccclc}
\hline Vial Number & Weight $(\mathrm{g})$ & Stain & \multicolumn{1}{c}{ Rf } & Fraction Number \\
\hline 1 to 2 & 0.0569 & 3 & $0.638 ; 0.654 ; 0.778$ & I \\
3 to 4 & 0.0644 & 2 & $0.202 ; 0.787$ & II \\
5 to 6 & 0.0332 & 3 & $0.622 ; 0.700 ; 0.783$ & III \\
7 to 9 & 0.0325 & 2 & $0.259 ; 0.781$ & IV \\
10 to 20 & 0.1429 & 1 & 0.789 & V \\
\hline
\end{tabular}

Description: Mean \pm SD; SD $=$ Standard Deviation.

Table 3. Results fraction I-V. Activity test to Enterobacter-5.

\begin{tabular}{ccrrr}
\hline \multirow{2}{*}{ Concentration } & \multirow{2}{*}{ Fraction } & \multicolumn{3}{c}{ Diameter of Inhibition Zone } \\
\cline { 3 - 5 } $20 \mu \mathrm{g} /$ disc & I & $13.05 \pm 0.51$ & $12.14 \pm 0.53$ & $11.05 \pm 0.40$ \\
& II & $13.18 \pm 0.34$ & $14.72 \pm 0.36$ & $13.30 \pm 0.08$ \\
& III & $10.98 \pm 0.38$ & $9.14 \pm 0.48$ & $9.67 \pm 0.20$ \\
& IV & $9.69 \pm 0.43$ & $8.25 \pm 0.68$ & $7.79 \pm 0.91$ \\
& V & $10.06 \pm 0.21$ & $9.32 \pm 0.29$ & $9.26 \pm 0.70$ \\
& control & $7.31 \pm 0.99$ & $7.06 \pm 0.78$ & $6.77 \pm 0.74$ \\
\hline
\end{tabular}




\begin{tabular}{ccrrr}
\hline \multirow{2}{*}{ Concentration } & \multirow{2}{*}{ Fraction } & \multicolumn{3}{c}{ Diameter of Inhibition Zone } \\
\cline { 3 - 5 } & & \multicolumn{1}{c}{$24 \mathrm{~h}$} & \multicolumn{1}{c}{$48 \mathrm{~h}$} & \multicolumn{1}{c}{$\mathrm{h}$} \\
\hline $40 \mu \mathrm{g} / \mathrm{disc}$ & I & $2.00 \pm 0.93$ & $11.12 \pm 0.72$ & $10.12 \pm 0.69$ \\
& II & $9.82 \pm 0.52$ & $8.89 \pm 0.74$ & $7.32 \pm 0.99$ \\
& III & $8.14 \pm 0.16$ & $7.65 \pm 0.72$ & $7.40 \pm 0.11$ \\
& IV & $8.60 \pm 0.87$ & $8.54 \pm 0.28$ & $8.28 \pm 0.85$ \\
& V & $7.29 \pm 0.96$ & $7.34 \pm 0.27$ & $7.27 \pm 0.24$ \\
$80 \mu \mathrm{g} / \mathrm{disc}$ & control & $11.80 \pm 0.48$ & $11.89 \pm 0.44$ & $11.53 \pm 0.62$ \\
& I & $14.90 \pm 0.55$ & $14.73 \pm 0.80$ & $14.57 \pm 0.11$ \\
& II & $10.91 \pm 0.61$ & $10.27 \pm 0.91$ & $10.30 \pm 0.88$ \\
& III & $8.01 \pm 0.64$ & $7.41 \pm 0.32$ & $7.26 \pm 0.05$ \\
& IV & $9.23 \pm 0.83$ & $9.14 \pm 0.65$ & $7.31 \pm 0.39$ \\
& V & $7.12 \pm 0.88$ & $7.59 \pm 0.06$ & $7.20 \pm 0.45$ \\
\hline
\end{tabular}

Description: Mean \pm SD; SD = Standard Deviation.

3.1.7. Sensitivity Test Against Klebsiella sp.

Test sensitivity of the bacteria Klebsiella sp. the ethyl acetate fraction showed that the fraction of the I - V have antibac-terial activity against bacteria Klebsiella sp (Table 4). Fraction-I know inhibition zone diameter increased up to $4 \mathrm{~h} h$ of incubation and decreased at $72 \mathrm{~h}$ of incubation. $20 \mu \mathrm{g}$ II fraction showed an increasing diameter of inhibition zone until $48 \mathrm{~h}$ of incubation, and it decreased in $72 \mathrm{~h}$ of incubation period. $80 \mu \mathrm{g}$ of IV fraction also had the similar activity. Meanwhile, the III and V fraction had a decreased diameter of inhibition zone during the incubation period.

Table 4. Results of sensitivity test bacteria Klebsiella sp. against fraction I - V.

\begin{tabular}{ccrrr}
\hline \multirow{2}{*}{ Concentration } & \multirow{2}{*}{ Fraction } & \multicolumn{3}{c}{ Diameter of inhibition zone } \\
\cline { 3 - 5 } $20 \mu \mathrm{g} /$ disc & I & $8.47 \pm 0.75$ & $78 \mathrm{~h}$ & $72 \mathrm{~h}$ \\
& II & $7.33 \pm 0.67$ & $7.36 \pm 0.50$ & $7.67 \pm 0.92$ \\
& III & $7.39 \pm 0.00$ & $7.22 \pm 0.42$ & $7.27 \pm 0.99$ \\
& IV & $7.80 \pm 0.91$ & $7.26 \pm 0.45$ & $7.21 \pm 0.83$ \\
& V & $7.43 \pm 0.68$ & $7.01 \pm 0.38$ & $7.00 \pm 0.95$ \\
& K & $7.26 \pm 0.55$ & $7.19 \pm 0.30$ & $7.10 \pm 0.93$ \\
$40 \mu$ g per disc & I & $9.20 \pm 0.51$ & $9.34 \pm 0.19$ & $8.86 \pm 0.47$ \\
& II & $8.92 \pm 0.96$ & $8.40 \pm 0.42$ & $7.69 \pm 0.22$ \\
& III & $8.05 \pm 0.28$ & $7.98 \pm 0.37$ & $7.63 \pm 0.08$ \\
& IV & $8.20 \pm 0.48$ & $7.61 \pm 0.13$ & $7.50 \pm 0.18$ \\
$80 \mu$ g per disc & V & $8.24 \pm 0.34$ & $7.79 \pm 0.14$ & $7.47 \pm 0.34$ \\
& K & $7.96 \pm 0.51$ & $7.65 \pm 0.76$ & $7.40 \pm 0.30$ \\
& I & $10.47 \pm 0.60$ & $10.63 \pm 0.71$ & $10.13 \pm 0.43$ \\
& II & $11.50 \pm 0.77$ & $11.10 \pm 0.96$ & $11.06 \pm 0.83$ \\
& III & $9.67 \pm 0.84$ & $9.85 \pm 0.74$ & $9.55 \pm 0.65$ \\
& IV & $9.01 \pm 0.66$ & $9.32 \pm 0.26$ & $8.14 \pm 0.75$ \\
& V & $9.83 \pm 0.54$ & $9.47 \pm 0.73$ & $9.27 \pm 0.99$ \\
& K & $7.12 \pm 0.89$ & $7.16 \pm 0.78$ & $6.93 \pm 0.71$ \\
\hline
\end{tabular}

Description: Mean \pm SD; SD = Standard Deviation. 
II fraction has the highest activity against Klebsiella sp. at $80 \mu \mathrm{g}$ per disc. While V fraction had the lowest activity against bacteria Klebsiella sp. at a concentration of 20, 40 and $80 \mu \mathrm{g}$ per disc.

\subsubsection{Gas Chromatography-Mass Spectrometer (GC-MS)}

Gas Chromatography-Mass Spectrometer (GC-MS) Fraction Analysis GC-MS analysis performed on II fraction, since this fraction has the best antibacterial activity.
Bioactive compound analysis using Gas Chromatography showed that there are four compounds were detected from fraction-II. The chromatogram II fraction can be seen in Figure 1.

The GC-MS chromatogram showed there are at least four peaks of II fraction that contained four compounds. The mass spectra identifications gave more specific to confirmation of chemical structure of the compound as shown in Table 5.

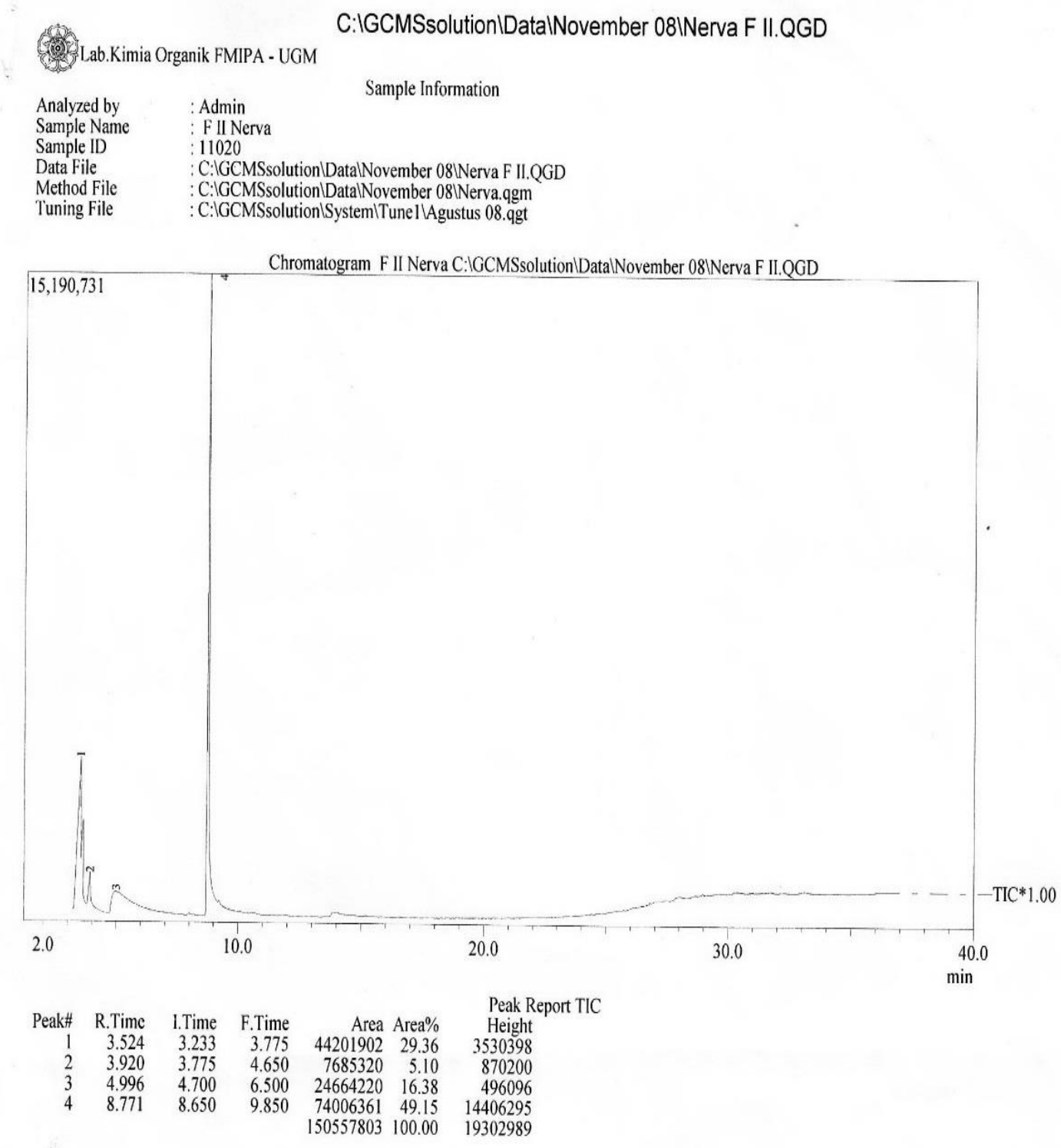

Figure 1. GC-MS chromatogram of fraction-II. 
Table 5. Results of analysis of fraction II by GC-MS.

\begin{tabular}{cccl}
\hline $\begin{array}{c}\text { Peak } \\
\text { Number }\end{array}$ & Retention Time & Peak Area $(\%)$ & \multicolumn{1}{c}{ Compound } \\
\hline 1 & 3.233 & 29.36 & 3-methyl-butanoic acid \\
2 & 3.775 & 5.10 & Pentanoic acid \\
3 & 4.700 & 16.38 & 2-butoxy-ethanol \\
4 & 8.650 & 49.15 & 2-Cyclohexenon \\
\hline
\end{tabular}

\section{DISCUSSION}

To compare the effects between sea cucumber extracts and commercial antibiotics, antibacterial activity tests were performed with antibiotics amoxicillin and streptomycin. Positive and negative control test were conducted to determine the effect of commercial antibiotics against bacteria and solvent test. Positive control test conducted with the use of antibiotics amoxicillin and streptomycin types. Tests using antibiotics aim to see the effects of antibiotics on bacteria test and compare it with the effect of sea cucumber extract against test bacteria which can be seen from the large diameter of the inhibition zone produced. When the sea cucumber extract inhibition zone larger than the diameter of inhibition zone of streptomycin, the sea cucumber extracts have great potential as a novel antibacterial compounds. Negative control test results showed that the antibiotic amoxicillin are not able to form a zone of inhibition while streptomycin was able to form a zone of inhibition of test bacteria. According to Wilson and Gisvold (2011) when compared with the group of amonoglycoside antibiotics (streptomycin), the potential class of penicillin antibiotics (amoxicillin) against gramnegative bacteria such as Klebsiella sp. and Enterobacter-5 is far less convincing. Negative control test conducted on the solvent n-hexane, ethyl acetate and methanol. The negative control test results showed that the three solvents did not result in inhibition zone against the test bacteria. So it was assumed that the presence of solvent in the extract had no influence on the formation of inhibition zones.

Antibacterial activity test was done to prove the potential of sea cucumber extract as an antibacterial compound against test bacteria. The test results of the antibacterial activity of sea cucumber extract against five different targeted bacteria, i.e. negative coagulant staphylococi (CNS), E. coli, Enterobacter-5, Klebsiella sp. and Pseudomonas sp., showed that not all of the antibacterial activity of sea cucumber extract looks at the test bacteria. Sea cucumber extract with solvent $n$ hexane was not active against bacteria fifth test, sea cucumber extract with ethyl acetate solvent is active against bacteria fifth test, while the methanol extract of the sea cucumber is only active in the CNS bacteria, Enterobacter-5 and Klebsiella sp. The test results showed that the antibacterial activity of semi-polar compounds found in sea cucumber extract has antibacterial activity against bacteria better CNS, E. coli, Enterobacter-5, Klebsiella sp. and Pseudomonas sp. of the sea cucumber extract with non-polar and polar compounds. According to Sendih and Gunawan (2006), extract semipolar to nonpolar directions over potentially toxic properties as difficult secreted by organisms compared to more polar com-pounds. Antibacterial activity of compounds sea cucumbers have long been known, such as the discovery of triterpenoid saponins which were known to be naturally anti-bacterial (Pringgenies, 2010; Simoes et al., 1999; Adibpour et al., 2014). Microbiostatic effect had been detected from the coelomic fluid of Holothuria leucospilota from Persian Gulf 
and Oman Sea against E. coli, Salmonella typhi, Staphylococus aureus and Pseudomonas aeruginosa, at concentration of $1.000 \mu \mathrm{g} \mathrm{mL}^{-1}$ and $2.000 \mu \mathrm{g} \mathrm{mL}^{-1}$, respecttively (Adibpour et al., 2014).

Determination by TLC eluent test serves to determine the best solvent in the separation of compounds with open column chromatography. Based on the results of testing by TLC, the best separation of the components of sea cucumber extract is obtained by using a mixture of ethyl acetate eluent: $n$-hexane in the ratio $1: 1$. TLC test results using the eluent mixture showed five spots. The a bility of eluent to separat the compounds of the ethyl acetate extract exhibited by many stains that are formed in the TLC plate. Stain produced by the ethyl acetate extract of the sea cucumber has a light yellow color. Therefore, a UV lamp was used to detect the stains on the TLC plate (Roth and Gottfried, 1988). Variety of Rf values in the TLC test (Table 2) shows that polarity variability of compound in the ethyl acetate extract. Each compound has a different Rf, so differences between stains on the TLC plate showed the presence of different compounds (Fessenden and Fessen-den, 1983). OPC fractionation with silica gel adsorbent done with because they are polar widely been used in the separation of different types of groups of hydrocarbons, alcohols, acids and other compounds (Pavia et al., 1995).

Eluent that been used was a mixture of ethyl acetate and n-hexane in the ratio 1: 1 . It is intended that the compounds contained in the ethyl acetate extract can be separated properly and optimally based on the polarity (Fessenden and Fessenden, 1983). Based on the results obtained OPC 5 fractions carried by TLC analysis of 20 vials with volume of 5 $\mathrm{mL}$ The five fractions obtained, fraction- $\mathrm{V}$ was found as the largest fraction weighing $0.1429 \mathrm{~g}$ of extract, where the least fractionIV extract weighing $0.0325 \mathrm{~g}$.

Sensitivity test of bacteria to the fraction of sea cucumber extract performed on selected test bacteria, namely Entero-bacter-5 and Klebsiella sp., since this fractions showed the most inhibition activeity against Enterobacter-5 and Klebsiella sp. The difference caused by the toxic activity of a compound caused by each compound will work or react specifically to the target (Trianto et al., 2004). Increasing of the incubation period, the inhibition zone tend to increase and decrease the diameter and brightness. An increase and a decrease in inhibition zone diameter and incubation period can be used to determine an antibacterial is bacteriostatic or bactericidal. An antibacterial agent is bacteriostatic if the show constriction zone of inhibition and reduction in brightness after $24 \mathrm{~h}$ of incubation, but if it is able to form a clear zone of inhibition which remained until the incubation time of $48 \mathrm{~h}$ then it is called a bactericidal antibacterial agents (Wattimena et al., 1985). The fifth test antibacterial activity against bacterial fractions test (Table 4 and Table 5) at a concentration of $20 \mu \mathrm{g}$ per disc, $40 \mu \mathrm{g}$ per disc and $80 \mu \mathrm{g}$ per disc showed that fraction II is the most active fraction and is bacteriostatic against Entero-bacter-5 and Klebsiella sp.

Based on the observations of the incubation period can be seen that the diameter of inhibition zone is formed at a certain incubation time may experience a narrowing and reduction in brightness. The findings indicates that the compound was a bacteriostatic fraction of sea cucumber extract, with capability to inhibit the growth of test bacteria but not kill. Treatment with three concentrations of $20 \mu \mathrm{g}$ per disc, $40 \mu \mathrm{g}$ per disc and $80 \mu \mathrm{g}$ per disc, the largest zone of inhibition produced by II fraction at a concentration of $80 \mu \mathrm{g}$ per disc, so that the II fraction allegedly contains compounds that are bacteriostatic against Enterobacter-5 and Klebsiella sp. This finding indicates that the more higher the concentration of the extract, the more higher content of bioactive and antibacterial ability is getting stronger. This was consistent with the statement of (Prijono, 1994) that the higher the concentration of the extract, the higher the active ingredients that 
may improve the ability to inhibit the growth of test bacteria. Bacteriostatic compounds inhibit protein synthesis by binding to ribosomes, bonding caused by a bacteriostatic compound was not so strong and when the concentration of these compounds is low or decreased stability, bacteriostatic compounds will release the bond to the ribosome so that bacteria can breed again (Brock and Madigan, 1991). The average value with highest inhibition zone was found at a concentration of $80 \mu \mathrm{g}$ per disc, that was $(14.73 \pm 0.48) \mathrm{mm}$ for the Enterobacter-5 and $(11.22 \pm 0.85) \mathrm{mm}$ for the Klebsiella sp. The second different sensitivity of bacteria to extract fractions sea cucumbers were suspected caused by the differences in the structure of the cell wall in bacteria Enterobacter-5 and Klebsiella sp. The five test results showed that the sensitivity of the bacteria Entero-bacter-5 was more sensitive to the fraction of sea cucumber extract than bacteria Klebsiella sp. Some class of bacteria in the genus of Enterobacter-5 has no capsule, so that it was suspected that bacterium Enterobacter-5 is one type of bacteria that do not have a capsule and cause easily killed by anti-microbial compound. The cell wall structure of gram negative bacteria were believed to be more complex, that is on the outside of the peptidoglycan polymer which contained three lipoproteins, outer membrane and liposaccharide (Astuti et al., 2003).

Bacteria can develop a self-defense mechanism to deal with something that could threaten its survival, such as changes in environmental conditions due to the presence of foreign substances or compounds that can interfere with the activity of the bacterial cell. This will attempt to neutralize the bacteria that enter foreign compounds. There are some bacteria are able to survive with the ability to neutralize these compounds, but some bacteria are able to survive and not die because it is not able to neutralize the foreign compounds (Nguyen et al., 2011). Other factors that may affect inhibitory concentration of microorganisms is antimicrobial, temperature, duration of antimicrobial substance applied to a microorganism, the sensitivity of microorganisms to antimicrobial materials and the population density of microorganisms. Differences in the ability of the antibacterial activity of the fifth fraction indicate that there is variation in the content of the compound of the fifth fraction. Broad inhibition zone formed around the paper disk was affected by the chemical properties of antibacterial compounds produced by a microorganism (Mariana et al., 2009). The rate of diffusion of molecules in the antibacterial compounds in agar medium, and the molecule is affected by the action of the order. Substances with a smaller molecular weight have a greater diffusion rate com-pared with a larger molecular weight.

The results of GC-MS analysis of the fraction II had detected four compounds were 3-methyl-butanoic acid, pentanoic acid, 2butoxy-ethanol and 2-cyclohexenon (Table $5)$. The four compounds were detected, 2cyclohexenon compound was found as a compound with the highest peak, which is $49.15 \%$ portion, while the compounds with the lowest peak with content of pentanoic acid $5.10 \%$ portion.

Above should be included in theresults of GC-MS. Where 3-methylbutanoic acid and pentanoate were known as the group of the fatty acids, Predicted, these compounds that affect the antibacterial activity. Research on the activity of bacterial symbionts as antibacteria has been done before as in Gastropods Conus miles (Pringgenies, 2009), Loligo sp. (Pringgenies and Apriliyani, 2012), sea cucumber Holothuria leucospilota (Pringgenies et al., 2014), Holothuria impatiens (Pringgenies et al., 2015). Two unsaturated fatty acids with potent $\alpha$-Glusidase inhibitory activity had been purified from the body wall of sea cucumber Stichopus japonicus (Omran and Allam, 2012; McLafferty, 1980). Methanolic extract of Sticopus badionotus showed antibacterial effects against $S$ aureus (McLafferty, 1980). In contrast (Kabara, 1978) 
found that the S. japonicus extract has no activity against gram positive and negative bacteria. As well as (Omran and Allam, 2012) showed that the tegument ethanol exctract of Holothuria leucospilata, H. polii, Bohadschia vitiensis and Actinopyga mauri-tania had no antibacterial effects against $E$. coli (gram negative) and B. subtilus (gram positive). Those variable findings showed that the activity of the extract may be changed according to the method of the extraction (Omran and Allam, 2012). Acid compound was generally showed a clear molecular ion abundance. Fatty acids and their derivatives can have effect to micro-organisms by affecting their lipid membrane. This effect was mainly cause disturbances in the lipid phase and sub-sequently altering the permeability of the microorganism (Silchenko et al., 2012). Furthermore, fatty acids and their derivatives as chemicas compounds tend germicide lowest toxic properties (Loo and Don, 2012). As the statement of Adibpour et al. (2014) that some fatty acids can be used as an anticancer drug. As example, linoleic acid contained in cucumber Cucumis sativus were known as anticancer. Linoleic acids including essential fatty acids were usually found in vegetable and animal fats (Loo and Don, 2012). Cyclohexane compound contained in Tapirira guianensis from French were also reported to function as an antibacterial (Silchenko et al., 2012). The compound of 2-butoxy-ethanol were known to frequent in hygiene products such as antibacterial soaps, antibacterial hand soap and disinfectant cleaning fluids. Extracts of the sea cucumber Stichopus vastus was found to be potential as an antibacterial activity to MDR, in particular to Enterobacter-5 and Klebsiella sp with the largest diameter of inhibition zone on the concentration of $80 \mu \mathrm{g}$ per disc. Based on the results of GC-MS analysis on fraction-II had confirmed the contained of four compounds namely acid 3methyl-butanoic, pentanoic acid, 2-butoxy ethanol and 2-cyclohexanon.

\section{ACKNOWLEDGEMENTS}

The authors would like to thanks to Ministry of Education, Directorate General of Higher Education for the research fund of Competition Research Grant No: 299A.1/ UN7.5/PG/2011, April, 18. 2011. Also special thanks to Prof. Ocky Karna Rajasa , PhD and Prof. Agus Sabdono $\mathrm{PhD}$ for their generous help on the methodology of the research and to Prof. A. Hartoko, PhD for the help in scientific English corrections. A sincere thanks also to all staff of the Natural Medicine Laboratory, Diponegoro University for the laboratory preparations and works.

\section{REFERENCES}

Adibpour, N., F. Nasr, F. Nematpour, A. Shakouri, and A. Ameri. 2014. Antibacterial and antifungal activity of Holothuria leucospilota isolated from Persian gulf and Oman sea. Judishapur J. Microbiol, 7(1):1-4.

Astuti, P.G. Alam, S.U.T. Pratiwi, T. Hertiani, dan S. Wahyuono. 2003. Antiinfection compound screening of sponge collected from Bunaken bay, Manado, Indonesia. J. Biota, 8:47-52.

Brocks, T.D. and M.T. Madigan. 1991. Biology of microorganism. $6^{\text {th }}$ ed. Prentice Hall, Engelwood Cliff. New Jersey. 775p.

Burgess, J.G., K.G. Boyd, E. Amstrong, Z. Jiang, L. Yan, B. Matz, U. May, T. Pisacane, A. Granmo, and D.R. Adam. 2003. The development of ma-rine natural product based antifouling paint. In: Taylor and Francis (ed). Biofouling. 197-205pp.

Fessenden and Fessenden. 1983. The technique and experiments of organic chemistry. PWS Publisher. USA. 52p.

Farjami, B., Nematollahi, M. Moradi, Y. Irajian, M. Nazemi, A. Ardebili, Abazar. 2013. Pournajaf International $J$. of Molecular and Clinical Microbiology, 1:225-230. 
Farjami, B., M. Nematollahi, Y. Moradi, and M. Nazemi. 2014. Derivation of extracts from Persian Gulf sea cucumber (Holothuria leucospilota) and assessment of its antifungal effect. Iranian J. of Fisheries Sciences, 13(4):785-795.

Gandjar, I.G. and A. Rohman. 2007. Chemical Pharmacy Analysis. Pustaka Pelajar. Yogyakarta. 490p.

Hashimoto, Y. 1979. Marine toxins and other bioactive marine metabolites. Japan Scientific Societies Press. Tokyo. $369 \mathrm{p}$.

Kabara, J.J. 1978. Fatty acid and derivatives as antimicrobial agents, a review. $I n$ : Kabara, J.J. The american oil chemists symposium on pharmacologycal effect of lipids. United States. 14p.

Lay, B.W. 1994. Laboratory microbial analysis. PT. Rajagrafindo Persada. Jakarta. 168p.

Loo, K.P. and M.M. Don. 2012. Jewel of the seabed: sea cucumber as nutritional and drug candidates. International $J$. of Food Science and Nutrition, 63(5):616-636.

Kristanti, N. and S. Aminah. 2008. Phytochemical. Teaching Book. Laboratory of Organic Chemistry. Fac. of Science. Airlangga. Surabaya. 165p.

Nakamura, C.V., T.U. Nakamura, E. Bando, A.F.N. Melo, D.A.G. Cortez, and B. R.D. Filho. 1999. Antibacterial Activity of Ocium gratissimum L. Essential Oil. Mem inst oswaldo Cruz, 94(5):675-678.

Nagarajappa and U. Goswami. 2007. Antibacterial Peptide from Coelomic Fluid of a Sea Cucumber. http:// www. nio.org. [Retrieved on 7 September 2007].

Mariana, N.S., M.A. Norfarrah, N. Kani, F.M. Yussof, and Arshad. 2009. Evaluating the antimicrobial activity and in vivo assay of methanolic exctract of Stichopus badionotus. International J. of Pharmacology, 5(3): 228-231.
McLafferty, F.W. 1980. Interpretation of mass-spectrometry. Sastrohamidjojo, H. (Translated). Gadjah Mada University Press. Yogyakarta. 1168p.

Nguyen, T.H., B.H. Um, and S.K. Kim. 2011. Two usaturated fatty acids with potent $\alpha$-glucosidase inhibitory activity purified from the body wall of sea cucumber Stichopus japonicus. J. of Food Science, 76(9):208-214.

Omran, N.E.E. and N.G. Allam. 2012. Screening of microbial contamination and antimicrobial activity of sea cucumber $H$. polii. Toxicology and Industrial Health, 29(10):944-954.

Pavia, D.L., G.M. Lampman, G.S. Kriz, and Engel. 1995. Introduction to organic laboratory techniques: a contemporary approach. W.B. Sounders College Publishing. Philadelphia. 1021p.

Prijono, D. 1994. The technical guide on the use of botanical insecticide. IPB Press. Bogor. 123p.

Pringgenies, D. 2010. Screening of symbiotic bacteria producing antimicrobial compound for multi drug resistant of gastropod Stramonita armigera from Ternate waters. J. Natur Indonesia, 13(3):187-199.

Pringgenies, D. and J.M. Jørgensen. 1994. Morphology of the luminous organ of the squid Loligo duvaucelii. Acta Zoologica, 75(4)305-309.

Pringgenies, D., S. Sastrodihardjo, N.R. Nganro, and Nyoman. 2001. Bacteria symbiosis in light organ of the Squid Loligo duvauceli and cuttlefish Sephia sp. Phuket Marine Biolical Center, Thailand, 25(1):145-148.

Pringgenies. D. 2009. Bioprospect of symbiotic bacteria of gastropod Conus miles to multi drug resistant (mdr) bacteria. J. Ilmu Kelautan, 14(1):4249.

Pringgenies. D. and P Apriliyani. 2012. Isolation and philogenetic analysis of luminecence bacteria symbiosis in light organ of Squid Loligo sp. In: 
Apriliyani (ed). Seminar Nasional Moluska Biodiversitas, Pengelolaan, Pemanfaatan dan Konservasi Moluska. Hlm.:72-79

Pringgenies. D. 2013. Antibacterial activity of Sea Cucumbers harvested from Karimunjawa aktivitas antibakteri Teripang yang dipanen dari Karimunjawa. Squalen Bulletin of Marine and Fisheries Postharvest and Biotechnology, 8(2):87-94

Pringgenies. D., A. Ridlo, dan H. Pratiwi. 2014. Potential of Sea Cucumber Rivet Red Extract (Holothuria leucospilota) as antibacterial MDR (Multi Drug Resistant). Universitas Riau. 76hlm.

Pringgenies, D., K. Titianita, dan A. Ridlo. 2015. Bioaktivitas ekstrak teripang Holothuria impatiens terhadap Bakteri Multi Drug Resistant (MDR). Pertemuan Ilmiah Tahunan Perhimpunan Mikrobiologi Indonesia. 978p.

Roth, H.J. and B. Gottfried. 1988. Pharmacology analysis. Gadjah Mada University Press. Yogyakarta. 565p.

Roy, K. 1982. Responses of five holothurian species to attacks by a predatory gastropod, Tonna perdix. Pacific Science, 36(4):445-450.

Sendih, S. and Gunawan. 2006. Noble character of sea cucumber for drugs. Agro Media Pustaka. Jakarta. 64p.

Silchenko, A.S., A.I. Kalinovsky, S.A. Avilov, P.V. Andryjaschenko, P.S.
Dmitrenok, E.A. Yurchenko, and V.I. Kalinin. 2012. Structures and cytotoxic properties of Cucumariosides $\mathrm{H} 2, \mathrm{H} 3, \mathrm{H} 4$ from the sea cucumber Eupentacta fraudatrix. Natural Product Research, 26(19):1765-1774.

Shimada, S. 1969. Antifungal steroid glycoside from sea cucumber. Science, 163:1462-1471.

Simoes, C.M., M. Amoros, and L. Girre. 1999. Mechanism of antiviral activity of triterpenoid saponins. Phytother Res, 13(4):323-328.

Trianto, A., Y.H. Yan, A.S. Ambariyanto, and R. Murwani. 2004. Test of gorgonian Isis hippuris extract to Artemia Salina Nauplii. J. Ilmu Kelautan, 9:61-66.

Wattimena, J.R., C. Nelly, Sugiarso, M.A. Widianto, E.Y. Sukandar, A.A. Soemardji, and A.R. Setiadi. 1985. Pharmacodynamic and antibiotic treatment. Yogyakarta Gajahmada University Press. 168p.

Wilson, C.O. and O. Gisvold. 2011. Wilson and Gisvold textbook on chemical pharmacology and organic medical. $8^{\text {th }}$ Ed. Lippincott Company. Philadelphia. 984p.

Yazid, E. 2005. Physical chemical for paramedics. Andi Press. Yogyakarta. 230p.

Diterima : 16 Juni 2017

Direview : 26 Juni 2017

Disetujui : 30 November 2017 
